Original article

\title{
Variability in benthic oxygen fluxes during the winter-spring transition in coastal sediments: an estimation by in situ micro-electrodes and laboratory mini-electrodes
}

\section{Variabilité des flux benthique d'oxygène pendant la transition hiver-printemps dans les sédiments côtiers : estimation par micro-électrodes in situ et par mini-électrodes au laboratoire}

\author{
Bruno Lansard ${ }^{\text {a,b }}$, Christophe Rabouille ${ }^{\mathrm{a}, *}$, Delphine Massias ${ }^{\mathrm{b}}$ \\ ${ }^{a}$ Laboratoire des Sciences du Climat et de l'Environnement, Avenue de la terrasse, 91198 Gif sur Yvette, France \\ ${ }^{b}$ Centre d'Océanologie de Marseille, rue de la batterie des Lions, Université de la Méditerranée, Marseille 13007, France
}

Received 12 July 2002; received in revised form 17 December 2002; accepted 10 January 2003

\begin{abstract}
Two expeditions were achieved at the winter-spring transition in the Golfe de Fos (Mediterranean Sea) at a site situated at $21 \mathrm{~m}$ depth. An in situ autonomous oxygen profiler and laboratory oxygen mini-electrodes were used to measure the oxygen distribution in the sediments and calculate the diffusive oxygen fluxes. Clearer waters during the second expedition promoted a rapid shift from a net heterotrophic environment to a photosynthesis-dominated sediment. The diffusive exchange fluxes of oxygen through the sediment-water interface varied from an average consumption of $5.3 \mathrm{mmol} \mathrm{m} \mathrm{d}^{-1}$ (February) to a net production of $12 \mathrm{mmol} \mathrm{m}^{-2} \mathrm{~d}^{-1}$ (March). At both periods, a large spatial heterogeneity was recorded by the different electrodes, with a larger difference between oxygen profiles when photosynthesis was active. This is probably indicative of a coupling between photosynthesis and respiration in hot spots located close to the photosynthetic organisms. The comparison between in situ micro-electrode profiles and laboratory mini-electrode measurements revealed a good agreement when respiration was dominant, but photosynthetic activity was not detected by the laboratory mini-electrode profiles.
\end{abstract}

(C) 2003 Éditions scientifiques et médicales Elsevier SAS and Ifremer/CNRS/IRD. All rights reserved.

\section{Résumé}

Deux campagnes ont été effectuées lors de la transition entre l'hiver et le printemps dans le golfe de Fos (mer Méditerranée) à un site situé à 21 mètres de profondeur. Un profileur benthique autonome et des mini-electrodes de laboratoire ont été utilisés pour mesurer la distribution d'oxygène dans les sédiments et calculer les flux diffusifs d'oxygène. Lors de la seconde campagne, la présence d'eau moins turbide a entraîné un changement rapide passant d'un environnement dominé par l'hétérotrophie à un environnement où la photosynthèse est le processus le plus actif. Les flux d'échanges d'oxygène à l'interface eau-sédiment varient d'une consommation nette de $5.3 \mathrm{mmol} \mathrm{m}^{-2} \mathrm{~d}^{-1}$ (février) à une production nette de $12 \mathrm{mmol} \mathrm{m}^{-2} \mathrm{~d}^{-1}$ (mars). A chaque période, une grande hétérogénéité spatiale est enregistrée par les différentes électrodes; des différences plus importantes sont notées quand la photosynthèse est active. Ceci indique probablement un couplage entre photosynthèse et respiration dans des « points chauds » situés à proximité des organismes photosynthétiques. La comparaison entre les mesures effectuées par micro-électrodes in situ et par mini-électrodes de laboratoire montrent un bon accord dans des conditions où la respiration est dominante, mais la photosynthèse n'est pas detectée sur les profils des mini-électrodes de laboratoire.

(C) 2003 Éditions scientifiques et médicales Elsevier SAS and Ifremer/CNRS/IRD. All rights reserved.

Keywords: Oxygen; In situ micro-electrodes; Biogeochemistry; Carbon cycle; Coastal sediment

Mots clés : Oxygène ; Micro-électrodes in situ ; Biogéochimie ; Cycle du carbone ; Sédiment côtier

* Corresponding author.

E-mail address: rabouill@1sce.cnrs-gif.fr (C. Rabouille). 


\section{Introduction}

Oxygen consumption by marine sediments has been largely studied in order to determine benthic metabolism and organic carbon mineralization (Mackin and Swider, 1989; Rabouille and Gaillard, 1991; Glud et al., 1994; Sayles et al., 1994; Cai et al., 1995; Sauter et al., 2001). In fact, the organic matter reaching the sea floor is degraded and recycled by a range of benthic microbial metabolisms (Froelich et al., 1979; Canfield et al., 1993a) including oxic mineralization, which takes place in the earlystages of sedimentary organic matter degradation. The consumption of oxygen by coastal sediments is responsible for extensive hypoxia in several estuaries and eutrophicated coastal zones (Justic, 1991; Justic et al., 1994; Nixon, 1995; Zimmerman and Canuel, 2000). In these sediments, oxygen is also an important control on the mobility of elements like phosphate, manganese, sulfide, etc. (Emerson et al., 1984; Sundby et al., 1986; Canfield et al., 1993b; Thamdrup et al., 1994). Dissolved $\mathrm{O}_{2}$ has a major influence on fluxes of redox-sensitive metals and associated species like $\mathrm{Fe}, \mathrm{Cu}, \mathrm{Ni}, \mathrm{Cd}, \mathrm{Zn}, \mathrm{Pb}$ (Klinkhammer et al., 1982; Westerlund et al., 1986; Gerringa, 1990; Van Ryssen et al., 1998; Zoumis et al., 2001; Ngiam and Lim, 2001) which cause environmental and health-related problems. A better understanding of oxygen biogeochemical cycle in coastal sediments and its variations with time during the seasons is needed to assess the impact of natural or anthropogenic perturbations (Rabouille et al., 2001).

Oxygen distribution results from the complex interplay between physical processes (diffusion, sedimentation), chemical reactions (oxidation of reduced species) and biogeochemical processes such as photosynthesis or respiration. To estimate the net rates of production or consumption, oxygen distribution in sediments achieved with polarographic mini- or micro-electrodes can be used (Helder and Bakker, 1985; Revsbech and Jørgensen, 1986).

This paper presents oxygen profiles obtained by in situ micro-electrodes and laboratory mini-electrodes in marine sediments of a Mediterranean coastal environment heavily impacted by industrial activity (Golfe de Fos, France). $\mathrm{O}_{2}$ fluxes at the sediment-water interface, reaction rates recalculated following Berg et al. (1998) and penetration depths of oxygen are evaluated for two cruises at a 1 month interval. They provide two contrasted situations due to the presence or absence of benthic primary production which influences largely the net flux of oxygen between the water column and the sediment. The in situ profiles are compared to laboratory measurements as a cross check of the two techniques.

\section{Materials and methods}

\subsection{Study site and sampling methods}

In situ measurements were carried out at site Hycarfos $\left(43^{\circ} 22.364^{\prime} \mathrm{N}, 4^{\circ} 59.674^{\prime} \mathrm{E}\right)$, in the Golfe de Fos near Marseille (France) during February and March 2000 (Fig. 1). Mean water depth was $21 \mathrm{~m}$ at the station. The sea floor was composed of muddy-sand sediments characterized by intense bioturbation. Burrows were visible at the sediment surface and care was taken to make measurements out of these burrows. Sediment cores with undisturbed surface structures were also sampled by divers using $25 \mathrm{~cm}$ PVC core liners (i.d. $11 \mathrm{~cm}$ ). They were capped in the water with no air bubble inside and transported to the laboratory in a cool box. In the lab, cores were stored at in situ temperature until clear

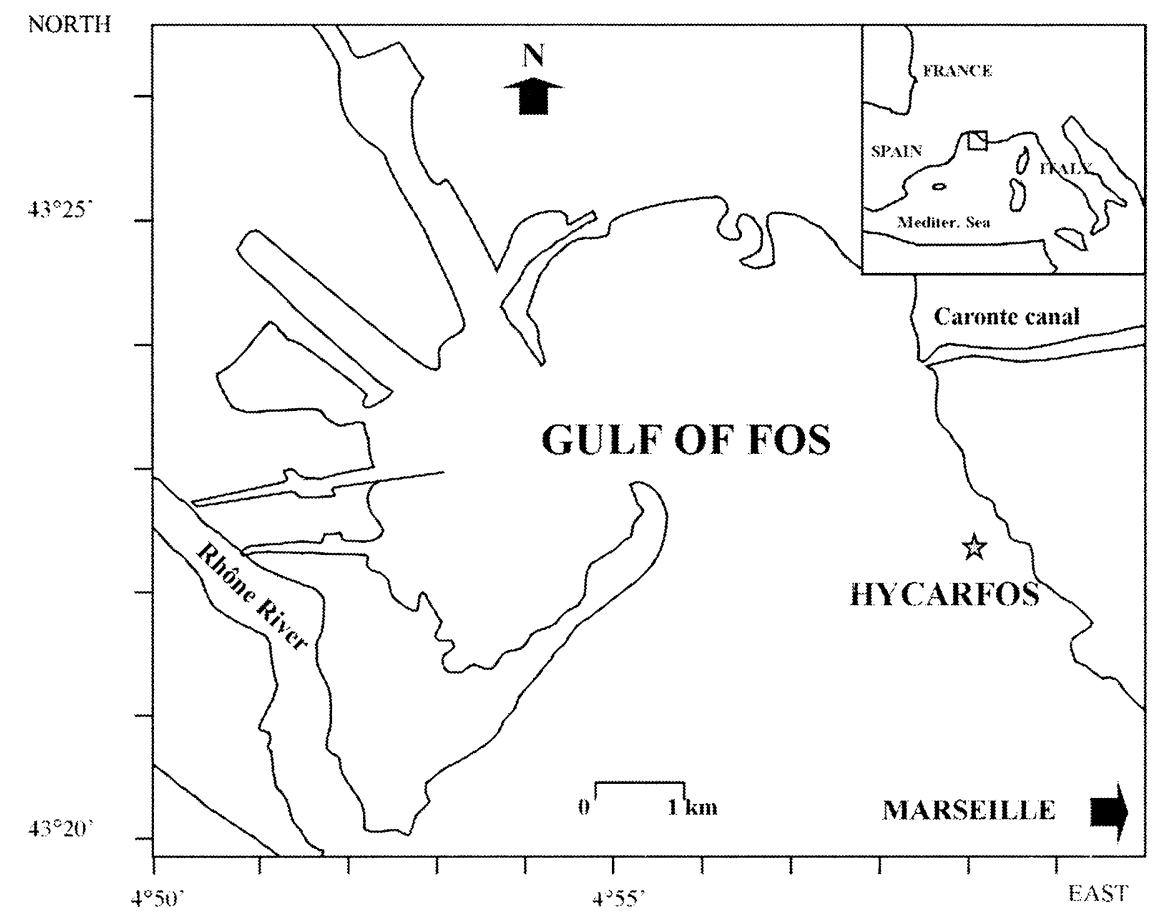

Fig. 1. Map of the Golfe de Fos with the location of the study site Hycarfos. 
overlying water (about $1 \mathrm{~h}$ ). During the expedition, bottomwater was sampled by diving with Niskin bottle for determination of salinity, temperature and dissolved oxygen. In February and March, water temperature and salinity at Hycarfos were 12.3 and $35.5^{\circ} \mathrm{C}$, and 13.8 and $35.9^{\circ} \mathrm{C}$, respectively.

\subsection{In situ micro-electrodes measurements}

Profiles of dissolved $\mathrm{O}_{2}$ and formation factor were measured in situ across the sediment-water interface at site Hycarfos. We used an in situ benthic microprofiling instrument, Unisense deep-sea profiler (Black et al., 2001), based on the design of Reimers (1987). The profiler, mounted on a tripodal frame, was settled on the sea floor by divers with minimum disturbance of sediment.

Dissolved $\mathrm{O}_{2}$ concentrations were measured by polarographic oxygen micro-electrodes provided with a built-in reference and an internal guard cathode (Revsbech, 1989). The $\mathrm{O}_{2}$ microsensors had tip outer diameters of $100 \mu \mathrm{m}$, a stirring sensitivity of $<1 \%$ (i.e. signal increase in flowing vs. stagnant water), a $90 \%$ response time $<10 \mathrm{~s}$, and the current drift was less than $2 \%$ per hour. The zero oxygen currents were typically on the order of 0-12 pA, in accordance with values measured in the laboratory with an ascorbate salt solution, and the bottom-water signals ranged from 270 to $480 \mathrm{pA}$, depending on the exact geometry of the electrode tip (Gundersen et al., 1998). The electrode signals were recorded in the overlying water both before and after the profile, to access the stability of the measurements. Linear calibration of micro-electrodes was achieved between bottom water value estimated by Winkler titration (Grasshoff et al., 1983) and the anoxic zone of the sediment. The vertical resolution of the measurements was $500 \mu \mathrm{m}$ in February and $100 \mu \mathrm{m}$ in March.

The position of the sediment-water interface relative to the in situ oxygen profiles was determined from $\mathrm{O}_{2}$ microprofiles. The classical technique (Sweerts and Cappenberg, 1988; Revsbech, 1989) consists in assigning the interface position to a break in the oxygen concentration gradient due to the increased diffusion coefficient in the sediment compared to the diffusive boundary layer. Since the resolution of the profiles in February was $0.5 \mathrm{~mm}$ at best, a distance similar to the thickness of the diffusive boundary layer (Gundersen and Jørgensen, 1990), we could not use this classical technique to determine the position of the sediment-water interface. As a consequence, with our low resolution of February, we imposed the interface position to the second point where the concentration variation was larger than the noise of the constant reading of the water column. The uncertainty is thus $\pm 500 \mu \mathrm{m}$ on the interface position for this period. In March, where the resolution was $100 \mu \mathrm{m}$ and a peak of $\mathrm{O}_{2}$ was detected, we assigned the interface position to the start of the oxygen increase with a thin DBL of 100-200 $\mu \mathrm{m}$. Oxygen penetration depth was determined from $\mathrm{O}_{2}$ profiles as the depth where the signal of the $\mathrm{O}_{2}$ micro-electrode reached the zero current.
Resistivity measurements were made with an electrode similar to that described by Andrews and Bennett (1981). Four thin parallel wires were buried in a matrix of epoxy, with only their tips in electrical contact with seawater. Resistivity recordings were converted to formation factor values by the formulation of Berner (1980):

$$
\mathrm{F}=\mathrm{R}_{\mathrm{z}} / \mathrm{R}_{\mathrm{bw}}
$$

where $F$ is the formation factor, $R_{z}$ is the mean of the resistivity at a given depth $z$ and $R_{\mathrm{bw}}$ is the average resistivity in bottom-water. Formation factor profiles were determined with the micro-profiler both in situ and in the laboratory. The results were presented using the factor $F^{-1}$ that is proportional to porosity (Ullman and Aller, 1982). Concurrently, the sediment porosity, $\phi$ (pore water volume/total volume), was determined at $2 \mathrm{~cm}$ depth intervals from the weight loss upon drying at $60{ }^{\circ} \mathrm{C}$ during 2 weeks of sediment core segments of known weight and volume. Sediment density, which was measured with a helium pycnometer amounted to $2.56 \mathrm{~g} \mathrm{~cm}^{-3}$.

\subsection{Laboratory mini-electrodes measurements}

Sediment cores at in situ temperature were used for laboratory profiles using mini-electrodes, which were achieved according to the procedure of Thomas (1978) and Revsbech and Jørgensen (1986). Mini-electrodes consist of goldcovered platinum wire insulated in glass and glued into $1 \mathrm{~mm}$ outer diameter hypodermic needles of up to $15 \mathrm{~cm}$ length. The gold-plated tip ( $10 \mu \mathrm{m}$ i.d.) surrounded by epoxy resin is covered with a semi-permeable membrane of cellulose nitrate (De Wit et al., 1997). The sensing tip is around 10$50 \mu \mathrm{m}$ and the needle outer diameter is $1 \mathrm{~mm}$. The electrode had a linear response within $10-100 \%$ air saturation. The $90 \%$ response time was about 45 s. Electrode currents for $10 \%$ (bubbling with $\mathrm{N}_{2}$ ) and $100 \%$ air saturation of $\mathrm{O}_{2}$ at $20{ }^{\circ} \mathrm{C}$ were, respectively, $0.09-0.2$ and $1.2-2 \mathrm{nA}$. Values in the anoxic zone of the sediment were around $0.05-0.08 \mathrm{nA}$. Like in situ profiles, a two point linear calibration of the mini-electrodes was performed using the constant reading recorded in the anoxic part of the sediment and the dissolved oxygen concentration in the bottom-water. Mini-electrodes were attached to a micromanipulator, and vertical profiles were recorded at $500 \mu \mathrm{m}$ in February and $200 \mu \mathrm{m}$ in March.

We note a potential problem of resolution with minielectrodes due to their diameter (around $1 \mathrm{~mm}$ ), which might introduce a physical disturbance of the sediment and alteration of the profile. However, for soft and muddy sediments, this perturbation is certainly minimal because gentle penetration of the needle does not cause strong sediment compaction (De Wit, 1995).

\subsection{Calculation of reaction rates}

We used a software called Profile developed by Berg et al. (1998) to calculate net reaction rates for oxygen in sediments with variable porosity. Briefly, the programme consists in a 
model describing oxygen transport and reaction in several zones where the reaction rate is constant. The model minimizes the difference between the output profile and the observation by modifying the number of zones and the reaction rates in each zone. The output of the programme consists in net reaction rates (production-respiration) integrated over a given sediment layer. We used a unique porosity profile derived from the resistivity measurements to calculate the consumption rates from different electrode profiles. We performed sensitivity tests with Profile and calculated the reaction rates for mini- and micro-electrode profiles.

\section{Results}

\subsection{Oxygen profiles}

\subsubsection{February}

Fig. 2 shows laboratory and in situ oxygen profiles measured in February. The profiler was deployed two times. First with one $\mathrm{O}_{2}$ micro-electrode (in situ 1; spatial resolution: $1 \mathrm{~mm}$ ) and then with two micro-electrodes $10 \mathrm{~cm}$ apart (in situ 2 and 3; spatial resolution: $500 \mu \mathrm{m}$ ). Ten readings were taken by each sensor at each position over $10 \mathrm{~s}$. They displayed little and erratic variations (about 1\%) and were later averaged to yield individual data points for oxygen and formation factor profiles. The fourth profile (Lab 1) was made in laboratory with steps of $500 \mu \mathrm{m}$.

During this deployment, the bottom-water was saturated with oxygen at $262 \mu \mathrm{mol} 1^{-1}$. Oxygen distribution in pore

\section{$\mathrm{O}_{2}(\mu \mathrm{mol} / 1)$}

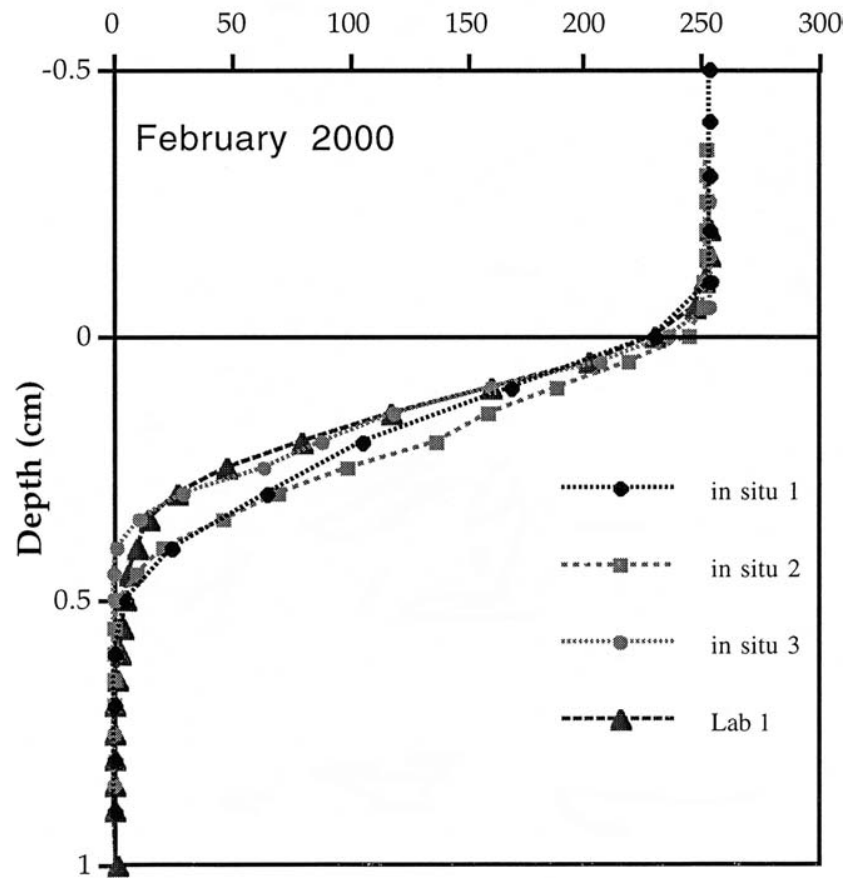

Fig. 2. In situ and laboratory oxygen profiles at site Hycarfos, February $2000\left(12.3^{\circ} \mathrm{C}\right)$. water decreased from bottom-water concentration in first linear and then concave downward profiles. General shape and oxygen gradients at the interface are similar for in situ and lab measurements. Oxygen penetration varies from 4.5 to $6 \mathrm{~mm}$ depth into the sediment between the three in situ profiles. At low $\mathrm{O}_{2}$ concentration, the signal of the minielectrodes drops rapidly, finally resulting in a larger $\mathrm{O}_{2}$ penetration, about $7 \mathrm{~mm}$. These depths of $\mathrm{O}_{2}$ penetration are typical in coastal sediment (Mackin and Swider, 1989; Rasmussen and Jørgensen, 1992). Below these depths, dissolved oxygen became undetectable.

\subsubsection{March}

In situ and laboratory oxygen profiles measured in March are presented in Fig. 3. The in situ deployment was achieved with two oxygen micro-electrodes (in situ 4 and 5) and a spatial resolution of $100 \mu \mathrm{m}$. In the laboratory, two profiles were done in the same core with steps of $200 \mu \mathrm{m}$ (Lab 2 and Lab 3).

In March, oxygen concentration in the bottom-water was $268 \mu \mathrm{mol} \mathrm{l}^{-1}$. In situ measurements with high spatial resolution showed a peak in oxygen concentration at or slightly below the sediment-water interface. These peaks are, respectively, 290 and $325 \mu \mathrm{mol} \mathrm{l}^{-1}$ for in situ 4 and 5, respectively. The layer where the oxygen concentration is elevated is only $800 \mu \mathrm{m}$ thick. For these profiles, oxygen penetration depths are $6.5 \mathrm{~mm}$ for in situ 4 and $4.9 \mathrm{~mm}$ for in situ 5 . The minimum depth penetration is associated with the larger oxygen peak. None of the two laboratory oxygen profiles show a peak at the interface. The general shape is similar for

\section{$\mathrm{O}_{2}(\mu \mathrm{mol} / 1)$}

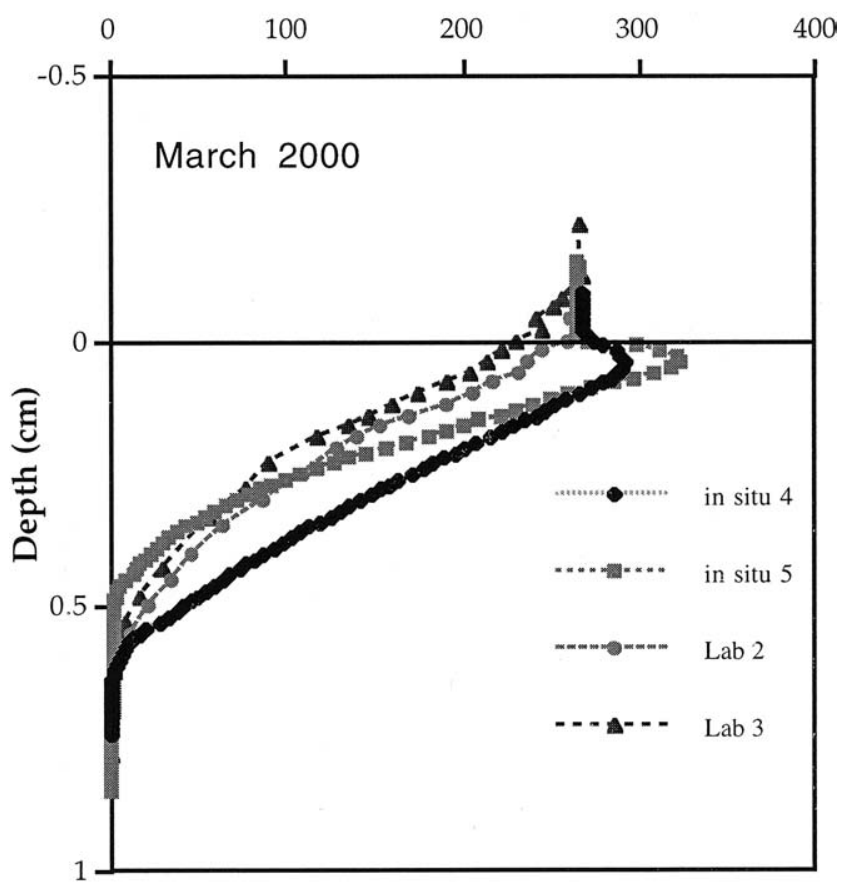

Fig. 3. In situ and laboratory oxygen profiles at site Hycarfos, March 2000 $\left(13.8^{\circ} \mathrm{C}\right)$. 
both profiles except at the sediment-water interface. One of them (Lab 3) suggests a decrease of oxygen concentration in the bottom-water above the sediment $(1 \mathrm{~mm})$, whereas Lab 2 does not. However, for both profiles, the gradients are similar in the sediment and the oxygen penetration is about $6 \mathrm{~mm}$.

A comparison between laboratory and in situ 4 profiles reveals similar negative slopes at high oxygen concentration. At low concentration, a change in slope is observed on mini-electrode profiles as already observed on February profiles.

\subsection{Resistivity and porosity results}

The porosity measured with a $2 \mathrm{~cm}$ step decreases gradually with depth from 0.50 for the top $2 \mathrm{~cm}$ to an average value of 0.43 at $20 \mathrm{~cm}$ depth (Fig. 4a). These profiles show relatively low values of porosity for coastal sediment but they are consistent with data reported by Jørgensen and Sørensen (1985).

Profiles of $F^{-1}$ measured in situ and in sediment cores have similar shapes (Fig. 4b). The $F^{-1}$ factor decreases from 1 in the bottom water to a mean value of 0.39 at $22 \mathrm{~mm}$ depth. $F^{-1}$ values decrease 3 or $4 \mathrm{~mm}$ above the sediment-water interface due to the interactions between the electrical field generated by the resistivity probe and the sediment (Andrews and Bennett, 1981; Archer et al., 1989). The uncertainty in locating the interface for our resistivity profiles is about $\pm 1 \mathrm{~mm}$. The location of the sediment-water interface for the in situ data set is estimated by assuming a similar behavior of the probe both in laboratory and in situ conditions. The $F^{-1}$ average value at the sediment-water interface would thus be $0.76 \pm 0.1$ for in situ measurements. The inverse of the formation factor $\left(F^{-1}\right)$ was calibrated against porosity using a simplified procedure from Andrews and Bennett (1981). We used the average $F^{-1}$ value between 2 and $3 \mathrm{~cm}(0.35)$ and the porosity measured by the water loss

\section{A.}

Porosity

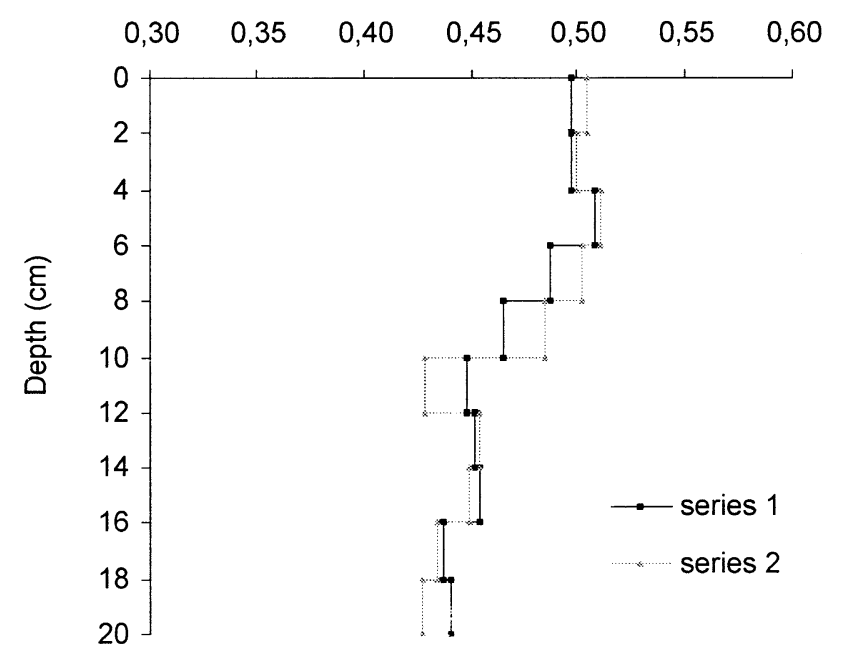

Table 1

Oxygen flux, net oxygen consumption and production rates (for different sediment layers when cited) estimated using the programme Profile from in situ and lab data of February and March. Between brackets are the zones over which this net rates are calculated

\begin{tabular}{llll}
\hline & $\begin{array}{l}\text { Oxygen flux in } \\
\mathrm{mmol} \mathrm{m}^{-2} \mathrm{~d}^{-1}\end{array}$ & $\begin{array}{l}\text { Oxygen } \\
\text { consumption } \\
\text { in mmol m }\end{array}$ \\
(sediment layer) & & $\begin{array}{l}\text { Oxygen } \\
\text { production in } \\
\text { mmol m }\end{array}$ \\
\hline February & $\mathrm{d}^{-1}$ \\
Lab 1 & 6.3 & 6.3 & - \\
In situ 2 & 3.9 & 3.9 & - \\
In situ 3 & 6.8 & 6.8 & - \\
March & & & - \\
Lab 2 & 4.4 & 4.4 & $10.4(0-1 \mathrm{~mm})$ \\
In situ 4 & -4.6 & $5.8(1-4 \mathrm{~mm})$ & $30.2(0-0.6 \mathrm{~mm})$ \\
In situ 5 & -19.3 & $10.9(0.6-5 \mathrm{~mm})$ & \\
\hline
\end{tabular}

technique (0.44). We assumed that $F^{-1}$ was related through a power law to porosity $\left(F^{-1}=\phi^{x}\right.$ Andrews and Bennett, 1981; Ullman and Aller, 1982). The relationship that we found was used to calibrate $F^{-1}$ against porosities:

$$
\mathrm{F}^{-1}=\phi^{1.28}
$$

The exponent of 1.28 falls in the lower range proposed by Ullman and Aller (1982) for low porosity sediment $(\phi<0.7)$.

\subsection{Oxygen flux calculation and integrated reaction rates}

The diffusive $\mathrm{O}_{2}$ fluxes at the sediment-water interface were estimated using both, the in situ and laboratory oxygen profiles with the Profile software. In March, where a peak of oxygen is present at or slightly below the sediment surface, the sediment is a net source of $\mathrm{O}_{2}$ to the water column. The diffusive flux of oxygen at the sediment-water interface is reported in Table 1.

A positive flux in this table indicates that the sedimentary column is a net heterotrophic environment (oxygen enters the sediment). The $\mathrm{O}_{2}$ fluxes calculated for mini- and micro-

B.

$\mathrm{F}^{-1}$

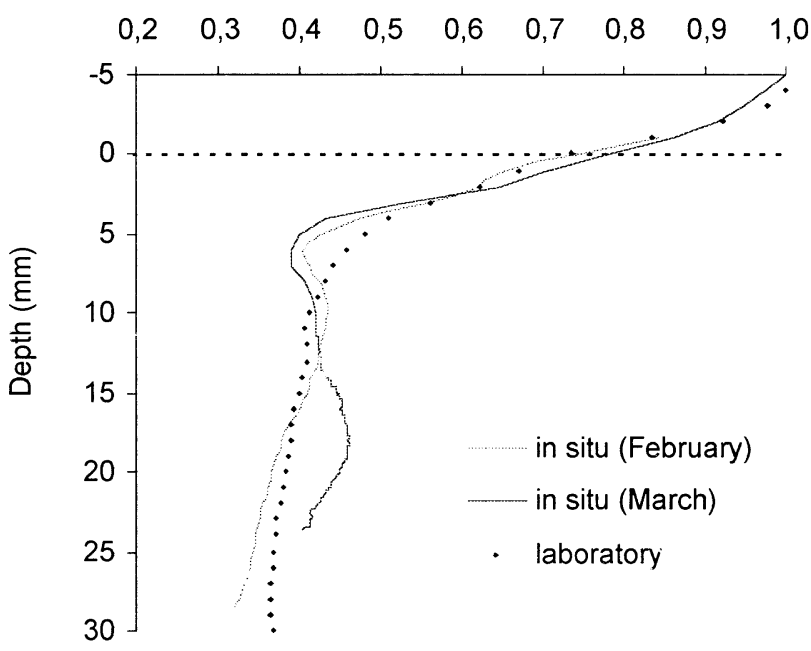

Fig. 4. Porosity profiles (A) measured in the lab and $F^{-1}$ profiles (B) realized from resistivity measurements made in situ and in the laboratory. 
electrodes in February are within a factor of 2. But the oxygen fluxes for in situ 3 and Lab 1 are quite similar, 6.8 and $6.3 \mathrm{mmol} \mathrm{m}^{-2} \mathrm{~d}^{-1}$, respectively. The two in situ microprofiles performed at the same time indicate a variation by a factor of 2, which underline a large lateral heterogeneity in this environment. For March, the net flux shows a large variability between the two in situ sensors (a factor of 4). The laboratory measurement shows a positive flux (towards the sediment) contrarily to the in situ profiles, which indicates that photosynthesis had not restarted at the time of laboratory measurement. The integrated oxygen consumption rates for in situ profiles range from 5.8 to $10.9 \mathrm{mmol} \mathrm{m}^{-2} \mathrm{~d}^{-1}$, whereas Lab 2 shows a slightly lower oxygen consumption rate (4.4 $\left.\mathrm{mmol} \mathrm{m}^{-2} \mathrm{~d}^{-1}\right)$.

\subsection{Sensitivity tests for porosity profiles using Berg's Model}

Sensitivity analysis was carried out concerning the role of the porosity profile in determining the rate distribution with depth. Indeed, most measured $\mathrm{O}_{2}$ profiles showed flat distributions below the sediment-water interface over 2-3 $\mathrm{mm}$. If porosity was constant, this flat part would signify that oxygen consumption is negligible and diffusion dominates. Since porosity variations are large in this portion of the sediment, the flat oxygen curve does indicate consumption but the rate is largely determined by the shape of the porosity profile. To illustrate this point, we have performed a calculation of reaction rates with Profile using constant porosity profiles and compared them to the calculation using a variable porosity profile. The constant porosity was set to 0.64 , the average of the variable porosity profile over the oxygen penetration depth (about $5 \mathrm{~mm}$ ). This value is different from the mean value measured on the first $2 \mathrm{~cm}$ but reflects the average of the resistivity calibrated values. Averaging the imposed porosity profile over $2 \mathrm{~cm}$ with an asymptot at 0.45 as proposed on Fig. 5 would yield a porosityof 0.5 , compatible with the macroscopic observations. Fig. 5 clearly shows the role of the porosity in determining the distribution of the consumption rate. When constant porosity is introduced, the rate distribution shifts towards depth. The integrated consumption rate is also different in both cases: it is $2.5 \mathrm{mmol} \mathrm{m}^{-2} \mathrm{~d}^{-1}$ for in situ 2 and $3.5 \mathrm{mmol} \mathrm{m}^{-2} \mathrm{~d}^{-1}$ for in situ 3 with constant porosity, between $35 \%$ and $45 \%$ lower than with variable porosity (3.9 and 6.8, respectively). Therefore, we used a variable porosity profile for our rate calculations.

\subsection{Distribution with depth of oxygen consumption/production rates}

We calculated the distribution with depth of net rates of oxygen consumption and production using the software published by Berg et al. (1998). It is important to point out that the rates calculated by the Profile software correspond to net rates calculated on separate sediment layers rather than gross rates. For example, the calculation of oxygen production in the top layer of the sediment in March corresponds to the sum of production-respiration in this layer, which certainly largely underestimates the gross primary production.

The distribution of oxygen consumption rate in the sediment were calculated for all profiles (Figs. 6 and 7 and integrated rates in Table 1). During February, the integrated rates varied between both in situ oxygen profiles by a factor of 2. The distribution with depth of the reaction rates is also very different between the two profiles: in situ 2 shows three reaction zones whereas in situ 3 shows only one, and in situ 2 exhibits a low consumption rate in the first millimeter and larger consumption deeper compared to in situ 3 consumption which spreads over most of the oxygen profile. The distribution with depth of the consumption rate calculated from laboratory mini-electrode data is consistent with in situ 2 showing lower consumption in the first millimeter and larger consumption at mid-depth, but the integrated reaction rates of the laboratory profile is two times larger than in situ 2. One important difference between the laboratory minielectrode and the in situ profiles is the consumption rate at the oxic-suboxic boundary. The laboratory profile indicates a very low consumption rate $\left(7.5 \mu \mathrm{mol} \mathrm{l}^{-1} \mathrm{~h}^{-1}\right)$ at its lower boundary, whereas both in situ profiles show consumptions larger than $40 \mu \mathrm{mol} \mathrm{l}^{-1} \mathrm{~h}^{-1}$.

In March, the large peak of oxygen at the sediment-water interface is the result of an intense photosynthesis with net $\mathrm{O}_{2}$ production rates ranging from 400 to $2000 \mu \mathrm{mol} \mathrm{l^{-1 }} \mathrm{h}^{-1}$. These net rates result from the competition between photosynthesis and respiration in each layer and do not correspond to gross primary production rates.

There is a large difference between the two profiles, which will be discussed in the next section. Deeper in the sediment where light is absent, respiration ranges between 100 and $300 \mu \mathrm{mol} \mathrm{l}^{-1} \mathrm{~h}^{-1}$ in contrast to oxygen consumption estimated in February at similar depths $\left(60-80 \mu \mathrm{mol} \mathrm{l}^{-1} \mathrm{~h}^{-1}\right)$. This indicates that mineralization is more active with photosynthesis than without it. Laboratory profile does not catch photosynthesis (the light conditions were not reproduced), and therefore, shows no oxygen peak and indicates lower oxygen consumption rates (around $80 \mu \mathrm{mol}^{-1} \mathrm{~h}^{-1}$ in subsurface sediment).

\section{Discussion}

\subsection{Temporal variability}

The measurements achieved in February and March showed two different environmental situations: In February, we encountered "classical" conditions with oxygen decreasing in pore waters from the overlying water concentration indicating net consumption of oxygen throughout the oxic sediment layer. The situation of March showed different characteristics with a peak of oxygen close to the sedimentwater interface showing benthic primary production at the sediment surface. Favorable light conditions were recorded at this period with exceptionally clear waters and sunny weather on the day where these oxygen profiles were mea- 
$\mathrm{O}_{2}$ consumption $(\mu \mathrm{mol} / \mathrm{l} / \mathrm{h})$
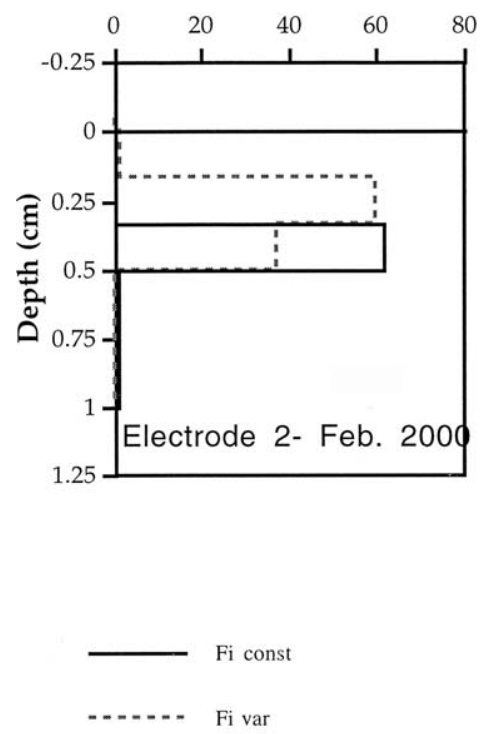

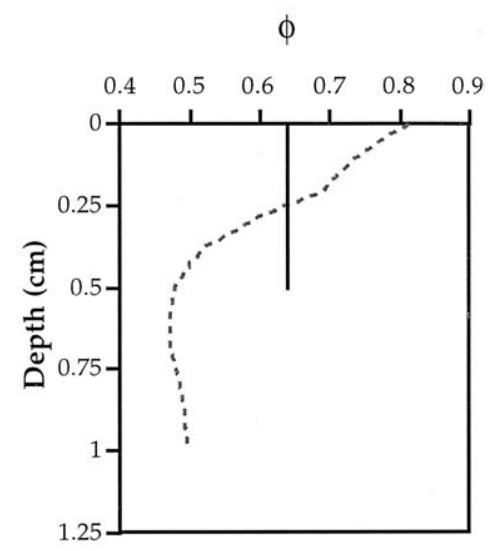

$\mathrm{O}_{2}$ consumption $(\mu \mathrm{mol} / \mathrm{l} / \mathrm{h})$

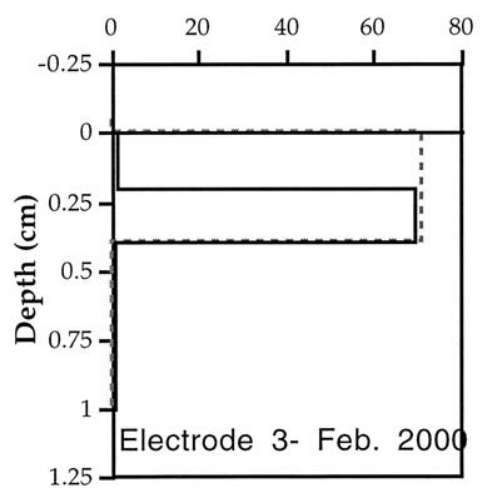

Fig. 5. Oxygen consumption rates for electrode in situ 2 and 3 (February 2000) calculated for different porosity profiles also shown. This serves as sensitivity test of the Profile software with respect to porosity profile.

sured (visual inspection by divers). Investigation of the sediment indicated the presence of sparse benthic pennate diatoms, which are known to achieve photosynthesis when significant light intensity penetrates to the sediment (Lindeboom, 1985). This resulted in oxygen peaks of 325 and $290 \mu \mathrm{mol} \mathrm{l}^{-1}$. Compared to previous studies of benthic primary production using $\mathrm{O}_{2}$ electrodes, these peaks are in the lower range since Revsbech et al. (1981) found oxygen peaks of five times saturation with day light conditions in the laboratory and Lindeboom et al. (1985) reported peaks of $650 \mu \mathrm{mol} \mathrm{l}^{-1}$ at $1.8 \mathrm{~m}$ depth with a dense diatom mat.

The net diffusive flux of oxygen at the sediment-water interface showed a large temporal variability between the two periods: a flux entering the sediment in February (3$6 \mathrm{mmol} \mathrm{m} \mathrm{m}^{-1}$ ) and a sediment as a net source of $\mathrm{O}_{2}$ to the water column in March ( -5 to $-19 \mathrm{mmol} \mathrm{m}^{-2} \mathrm{~d}^{-1}$ ). It is noteworthy that the onset of primary production is related to the occurrence of clear waters, which is linked to several factors (water turbidity, wind direction, resuspension intensity on the seashore, concentration of suspended matter, etc.) affected by daily variations in this region rather than by seasonal trends. The rapid change in oxygen profiles and calculated flux at this period indicates that the role of the benthic system in the oxygen mass balance for the Golfe de Fos can be largely variable on a daily basis. It ranges from a large sink to a large source even for sediments situated at $20 \mathrm{~m}$ depth. The sediment as a source is certainly restricted to special light penetration conditions (low turbidity, sunny conditions) but the source term can be very strong and could be significant in oxygen budgets. 


\section{$\mathrm{O} 2(\mu \mathrm{mol} / \mathrm{l})$}

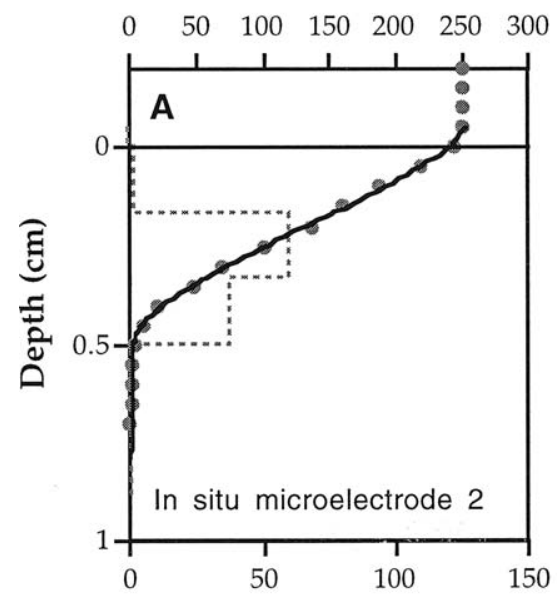

$\mathrm{O} 2$ consumption $(\mu \mathrm{mol} / \mathrm{l} / \mathrm{h})$
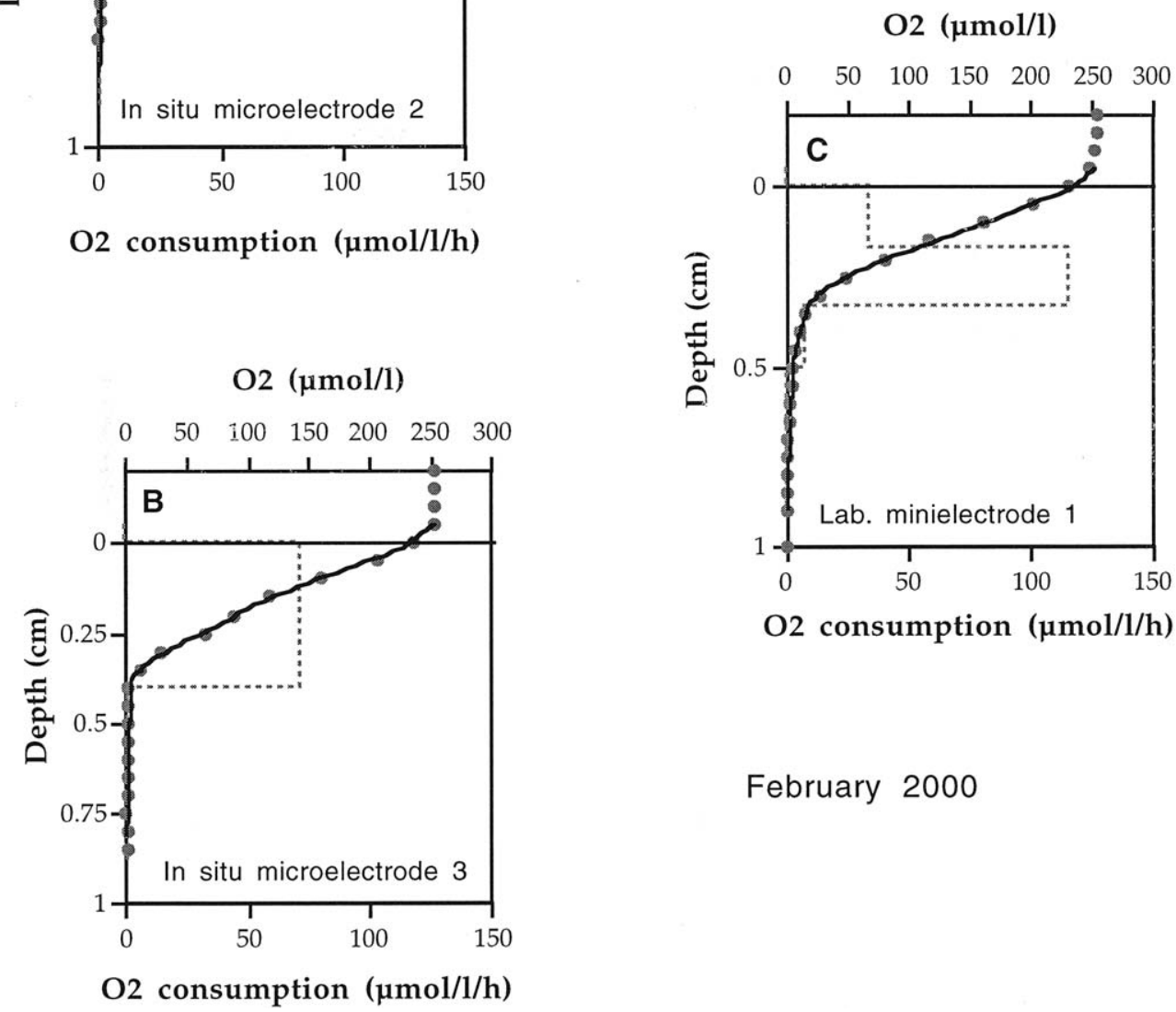

February 2000

Fig. 6. Oxygen distribution for February 2000 (dots), best fit using Profile (plain curve) and oxygen consumption rates calculated by profiles (dashed lines).

\subsection{Spatial heterogeneity}

As pointed out, mineralization rate and oxygen flux calculations show a large heterogeneity between the different in situ micro-electrodes. This is visible on the graphs and on the rate calculations performed by Profile. For in situ 2 and 3, the oxygen penetration varies by $1 \mathrm{~mm}$ over $4-5 \mathrm{~mm}$, and the gradients at the sediment-water interface are much steeper for in situ 3 resulting in an exchange flux two times larger. The contrast is even more striking for in situ 4 and 5 with a difference of $2 \mathrm{~mm}$ in the oxygen penetration. For these two profiles, the net fluxes are within a factor of 4, which represents a very large range.

It is obvious that micro-electrodes sample only a very small portion of the sea floor, which might introduce differences between the profiles because of the natural heterogeneity of surficial sediments. Several processes could lead to spatial variability among which differences in quality/ quantity of organic matter, thickness of the diffusive boundary layer linked to micro topography, presence and density of animal burrows and availability of reduced chemical species (Rabouille et al., 2002). These factors would contribute to the variability at the microprofile scale by modifying the local oxygen consumption or supply parameters.

Another aspect that should be taken into account for March situation is the fact that benthic primary production occurred through sparse benthic diatoms or small colonies of these microalgae. We think that in situ 5 profile is measured closer to a diatom aggregate than in situ 4 . As already underline by Fenchel and Glud (2000), in a photosynthetic sediment, horizontal distribution of $\mathrm{O}_{2}$ concentration revealed spatial heterogeneity at a millimeter scale with "hotspots" of intense photosynthesis and respiration. The proximity of the aggregate would thus be another factor of variability for both production and consumption of oxygen with the coupling of 


\section{$\mathrm{O} 2(\mu \mathrm{mol} / 1)$}

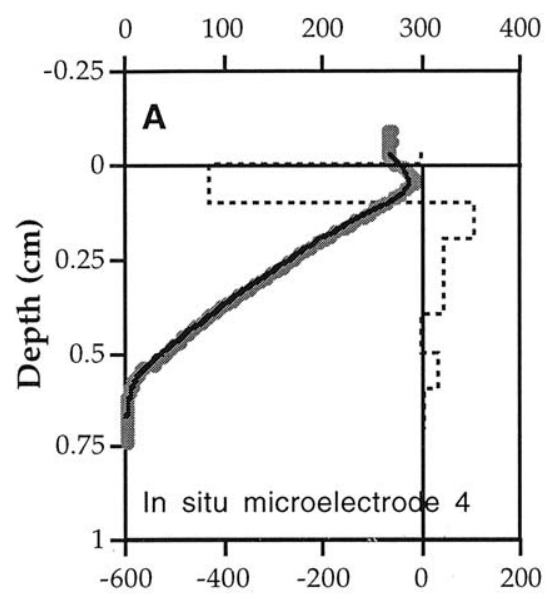

$\mathrm{O} 2$ consumption $(\mu \mathrm{mol} / \mathrm{l} / \mathrm{h})$

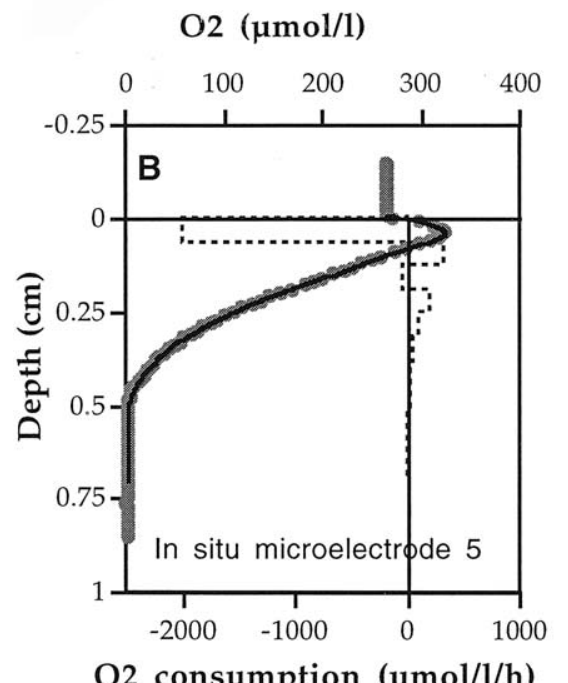

$\mathrm{O} 2(\mu \mathrm{mol} / \mathrm{l})$

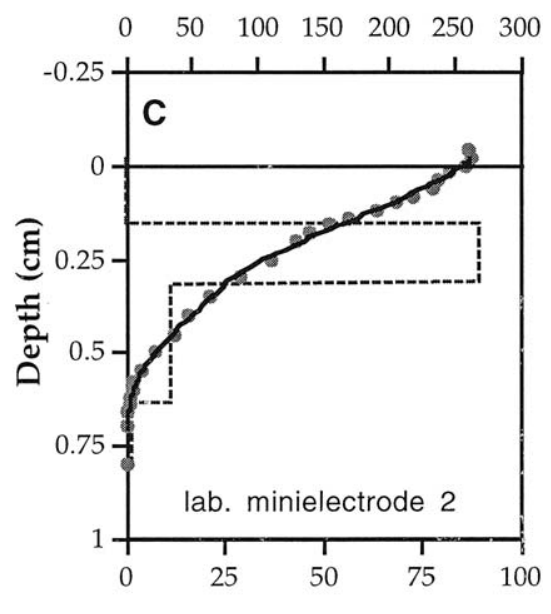

$\mathrm{O} 2$ consumption $(\mu \mathrm{mol} / \mathrm{l} / \mathrm{h})$

March 2000

Fig. 7. Oxygen distribution for March 2000 (dots), best fit using Profile (plain curve) and oxygen consumption rates calculated by profiles (dashed lines).

these two processes in the sediment. According to Fenchel and Glud (2000), sediment-water $\mathrm{O}_{2}$ exchange may vary by a factor of 3 and 10 for $\mathrm{O}_{2}$-uptake and $\mathrm{O}_{2}$-release, respectively, over distances of $2 \mathrm{~mm}$. The variability of our results are in the same range.

\subsection{Coupling between benthic production and respiration}

In March, where primary production was active in upper sediments, oxygen gradients in the sediment were different between the profiles, showing larger gradients at depth for the profile with the largest oxygen peak. In previous observations (Revsbech et al., 1981; Lindeboom et al., 1985), larger penetrations of oxygen were associated with larger oxygen peaks. Since these peaks are the consequence of benthic production, diffusion and consumption, larger pro- duction should create larger gradients and promote deeper penetration of oxygen in sediments. These previous studies showed that a large increase in penetration depth of oxygen (from 4 to $9 \mathrm{~mm}$ ) is associated to very large supersaturation (up to five times saturation, around $1300 \mu \mathrm{mol} \mathrm{l}^{-1}$ at $14{ }^{\circ} \mathrm{C}$, Revsbech and Jørgensen, 1983), whereas smaller oxygen supersaturations (below $650 \mu \mathrm{mol} \mathrm{l}^{-1}$ ) do not increase penetration by more than $1 \mathrm{~mm}$. Our observation of lower oxygen penetration occurring on the profile with the largest oxygen peak $\left(325 \mu \mathrm{mol} \mathrm{l}^{-1}\right)$ indicates that oxygen consumption linked to mineralization below the photosynthetic centers is more intense. Enhanced mineralization could be linked to diffusion of cell exudates of labile organic compounds during primary production or mineralization of exoproducts of cells during the photosynthetic process. This could be related to the conclusions of Lindeboom et al. 
(1985) who found that oxygen demand of sediment was larger in bell jars showing primary production (when placed in the dark) than bell jars kept continuously dark.

Since we calculated only net production/consumption rates, we cannot fully quantify the coupling between photosynthesis and respiration, which would require gross rates to be estimated. Nevertheless, we have a clear indication of larger net oxygen consumption in dark sediment layers (below $1 \mathrm{~mm}$ ) when net oxygen production in the top sediment layer are increased.

\subsection{Comparison of measurement techniques}

The two different conditions encountered in February and March allow the comparison of the performance of oxygen measurement systems in a wide range of conditions. In February, $\mathrm{O}_{2}$ profiles recorded using both laboratory and in situ techniques showed similar features: gradients at the sediment-water interface were equivalent for the two methods and oxygen penetration were slightly larger (by $1 \mathrm{~mm}$ ) for laboratory mini-electrodes compared to in situ microelectrodes. This might be the result of a lower sensitivity of the mini-electrodes at low oxygen concentration. In fact these electrodes show a linear calibration from $10 \%$ to $100 \%$ saturation, but calibration below $10 \%$ (ca. $25 \mu \mathrm{mol} 1^{-1}$ ) was not achieved. The slope of the mini-electrode at low $\mathrm{O}_{2}$ concentration could be different from the slope at higher concentration, resulting in this apparent slope break on the oxygen profile and deeper $\mathrm{O}_{2}$ penetration measured in the laboratory. This hypothesis remains to be tested. Nevertheless, a fair agreement between in situ and laboratory gradients is found below the sediment-water interface and flux calculations show similar values for the two techniques. In these conditions, sampling, transportation and laboratory measurement do not seem to modify the observed oxygen gradients. Great care was taken during sampling (by divers) and core transportation (cold conditions) to ensure preservation of the sediment interface. Furthermore, the temperature of the core was carefully re-adjusted to the in situ conditions in a dark cold room and oxygen bubbled in the overlying water before oxygen profiling, which is certainlya key to the measurement of reliable profiles. On the contrary, the different shapes of the profiles close to the oxic-anoxic boundary obtained by the two techniques point towards different biogeochemical processes: in situ profiles show large oxidation processes at the redox boundary and laboratory minielectrodes indicates preferential mineralization of organic matter closer to the sediment-water interface.

For the situation in March with oxygen supersaturation, the comparison of electrode signals recorded by in situ and laboratory techniques shows a clear difference. Laboratory profiles do not exhibit oxygen peaks. This is certainly the consequence of keeping cores in the dark from sampling to measurements and not reproducing in situ light conditions in the laboratory. Indeed, cores were capped and kept in a dark cold room until analysis causing a disruption of photosynthesis. Revsbech et al. (1981) showed that the time necessary to erase the oxygen peak was less than $6 \mathrm{~h}$ for an oxygen concentration of approximately $1300 \mu \mathrm{mol}^{-1}$. Around 3-4 h in the dark for our cores were certainly enough for the oxygen peak to be consumed.

\section{Conclusion}

Sediments studied with in situ micro-electrodes at the winter-spring transition in the Golfe de Fos at $21 \mathrm{~m}$ depth showed a dramatic shift from a situation where mineralization dominates to a situation where benthic primary production controls the exchange flux at the sediment-water interface. Between these two sampling periods, the magnitude and direction of the oxygen flux varied from an average

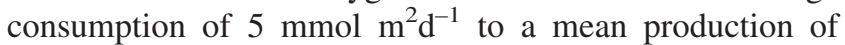
$12 \mathrm{mmol} \mathrm{m} \mathrm{m}^{-1}$ when the overlying water was clear enough to allow light penetration and photosynthetic activity. This indicates that opportunistic species can use light down to these depths and modify the exchange rate of oxygen between the sediment and the water column.

Our study also indicates that spatial heterogeneity exists down to a depth of a few millimeters in coastal sediments. We also provide additional information that primary production is very tightly coupled to respiration.

The comparison between in situ micro-electrodes and laboratory mini-electrodes showed a surprisingly good agreement for the situation dominated by respiration (February) for both profile shape and oxygen fluxes, but the situation with primary production was poorly captured by the laboratory mini-electrode setting.

\section{Acknowledgements}

We thank Pascal L'Henoret for his technical assistance, the captain and crew of the R.V. Antedon and R. Graille and C. Marschal for their diving work. This study was supported by the Laboratoire des sciences du climat et de l'environnement (CNRS/CEA). This is LSCE contribution XXXX.

\section{References}

Andrews, D., Bennett, A., 1981. Measurements of diffusivity near the sediment-water interface with a fine scale resistivity probe. Geochim. Cosmochim. Acta 45, 2169-2175.

Archer, D., Emerson, S., Reimers, C.E., 1989. Dissolution of calcite in deep-sea sediments: $\mathrm{pH}$ and $\mathrm{O}_{2}$ microelectrode results. Geochim. Cosmochim. Acta 53, 2831-2845.

Berner, R.A., 1980. Early Diagenesis: A Theoretical Approach. Princeton University Press.

Berg, P., Risgaard-Petersen, N., Rysgaard, S., 1998. Interpretation of measured concentration profiles in sediment pore water. Limnol. Oceanogr 43, 1500-1510.

Black, K.S., Fones, G.R., Peppe, O.C., Kennedy, H.A., Bentaleb, I., 2001. An autonomous benthic lander: preliminary observations from the UK BENBO thematic programme. Contin. Shelf Res 21, 859-877. 
Cai, W.J., Reimers, C.E., Shaw, T., 1995. Microelectrode studies of organic carbon degradation and calcite dissolution at a California Continental rise site. Geochim. Cosmochim. Acta 59, 497-511.

Canfield, D.E., Jørgensen, B.B., Fossing, H., Glud, R., Gundersen, J., Ramsing, N.B., Thamdrup, B., Hansen, J.W., Nielsen, L.P., Hall, P.O.J., 1993. Pathways of organic carbon oxidation in three continental margin sediments. Mar. Geol 113, 27-40.

Canfield, D.E., Thamdrup, B., Hansen, J.W., 1993. The anaerobic degradation of organic matter in Danish coastal sediments: iron reduction, manganese reduction, and sulphate reduction. Geochim. Cosmochim. Acta 57, 3867-3883

De Wit, R., Relexans, J.C., Bouvier, T., Moriarty, D.J.W., 1997. Microbial respiration and diffusive oxygen uptake of deep-sea sediments in the Southern Ocean (Antares-I cruise). Deep Sea Res. II. 44 (5), 1053-1068.

De Wit, R., 1995. Measurements of sedimentary gradients of pore water species by use of microelectrodes. Calculations of microbial metabolic processes in the sediments. Oceanis 21, 287-297.

Emerson, S., Jahnke, R., Heggie, D., 1984. Sediment-water exchange in shallow water estuarine sediments. J. Mar. Res 42, 709-730.

Fenchel, T., Glud, R.N., 2000. Benthic primary production and $\mathrm{O}_{2}-\mathrm{CO}_{2}$ dynamics in a shallow-water sediments: spatial and temporal heterogeneity. Ophelia 53, 159-171.

Froelich, P.N., Klinkhammer, G.P., Bender, M.L., Luedtke, N.A., Heath, G.R., Cullen, D., Dauphin, P., Hammond, D., Hartman, B., Maynard, V., 1979. Early oxidation of organic matter in pelagic sediments of the eastern equatorial Atlantic: suboxic diagenesis. Geochim. Cosmochim. Acta 43, 1075-1090.

Gerringa, L.J.A., 1990. Aerobic degradation of organic matter and the mobility of $\mathrm{Cu}, \mathrm{Cd}, \mathrm{Ni}, \mathrm{Pb}, \mathrm{Zn}, \mathrm{Fe}$ and $\mathrm{Mn}$ in marine sediment slurries. Mar. Chem 29, 355-374.

Glud, R.N., Gundersen, J.K., Revsbech, N.P., Jørgensen, B.B., Schulz, H.D., 1994. Diffusive and total oxygen uptake of deep-sea sediments in the Eastern South Atlantic Ocean: in situ and laboratory measurements. Deep-Sea Res 41, 1767-1788.

Grasshoff, K., Erhardt, M., Kremling, K., 1983. Methods of Seawater Analysis, second, revised and extended. Verlag Chemie.

Gundersen, J.K., Ramsing, N.B., Glud, R.N., 1998. Predicting the signal of $\mathrm{O}_{2}$ microsensors from physical dimensions, temperature, salinity, and $\mathrm{O}_{2}$ concentration. Limnol. Oceanogr 43, 1932-1937.

Gundersen, J.K., Jørgensen, B.B., 1990. Microstructure of diffusive boundary layers and the oxygen uptake of the sea floor. Nature 345, 604-607.

Helder, W., Bakker, J.F., 1985. Shipboard comparison of micro- and minielectrodes for measuring oxygen distribution in marine sediments. Limnol. Oceanogr 30, 1106-1109.

Jørgensen, B.B., Sørensen, J., 1985. Seasonal cycles of $\mathrm{O}_{2}, \mathrm{NO}_{3}{ }^{-}$and $\mathrm{SO}_{4}{ }^{2-}$ reduction in estuarine sediments: the significance of an $\mathrm{NO}_{3}{ }^{-}$reduction maximum in spring. Mar. Ecol. Prog. Ser. 24, 65-74.

Justic, D., Rabalais, N.N., Turner, R.E., 1994. Riverborne nutrients, hypoxia and coastal ecosystem evolution: biological responses to long-term changes in nutrient loads carried by the Pô and the Mississippi Rivers. In: Dyer, K.R., Orth, R.J. (Eds.), Changes in fluxes in estuaries: implications from science to management. Olsen and Olsen, Fredensborg, Denmark, pp. 161-167.

Justic, D., 1991. A simple oxygen index for trophic state description. Mar. Pollut. Bull 22, 201-204.

Klinkhammer, G.P., Heggie, D.T., Graham, D.W., 1982. Metal diagenesis in oxic marine sediments. Earth Planet. Sci. Lett 61, 211-219.

Lindeboom, H.J., Sandre, A.J.J., Driessche, H.A.J., 1985. A new bell jar/microelectrode method to measure changing oxygen fluxes in illuminated sediments with a microbial cover. Limnol. Oceanogr 30, 693-698.

Mackin, J.E., Swider, K.T., 1989. Organic matter decomposition pathways and oxygen consumption in coastal marine sediment. J. Mar. Res 47, 681-716.

Ngiam, L.S., Lim, P.E., 2001. Speciation patterns of heavy metals in tropical estuarine anoxic and oxidised sediments by different sequential extraction schemes. Sci. Total Environ 275, 53-61.
Nixon, S.W., 1995. Coastal marine eutrophication: a definition, social cause, and future concerns. Ophelia 41, 199-219.

Rabouille, C., Denis, L., Dedieu, K., Stora, G., Lansard, B., Grenz, C., 2003. Oxygen demand in coastal marine sediments: comparing in situ microelectrodes and laboratory core incubations. J. Exp. Mar. Biol. Ecol 285/286, 46-69.

Rabouille, C., Mackenzie, F.T., Ver, L.M., 2001. Influence of the human perturbation on carbon, nitrogen, and oxygen biogeochemical cycles in the global coastal ocean. Geochim. Cosmochim. Acta 65, 3615-3641.

Rabouille, C., Gaillard, J.F., 1991. A coupled model representing the deepsea organic carbon mineralization and oxygen consumption in surficial sediments. J. Geophys. Res 96, 2762-2776.

Rasmussen, H., Jørgensen, B.B., 1992. Microelectrode studies of seasonal oxygen uptake in a coastal sediment: role of molecular diffusion. Mar. Ecol. Prog. Ser 81, 289-303.

Reimers, C.E., 1987. An in situ microprofiling instrument for measuring interfacial pore water gradients: methods and oxygen profiles from the North Pacific Ocean. Deep-Sea Res 34, 2019-2035.

Revsbech, N.P., 1989. An oxygen microsensor with a guard cathode. Limnol. Oceanogr 34, 474-478.

Revsbech, N.P., Jørgensen, B.B., 1986. Microelectrodes: their use in microbial ecology. In: Marshall, K.C. (Ed.), Advances in Microbial Ecology, 9, pp. 293-352.

Revsbech, N.P., Jørgensen, B.B., 1983. Photosynthesis of benthic microflora measured with high spatial resolution by the oxygen microprofile method: capabilities and limitations of the method. Limnol. Oceanogr 28, 749-756.

Revsbech, N.P., Jørgensen, B.B., Brix, O., 1981. Primary production of microalgae in sediments measured by oxygen profile, $\mathrm{H}^{14} \mathrm{CO}_{3}{ }^{-}$fixation, and oxygen exchange methods. Limnol. Oceanogr 26, 474-478.

Sauter, E.J., Schlüter, M., Suess, E., 2001. Organic carbon flux and remineralization in surface sediments from the northern North Atlantic derived from pore-water oxygen microprofiles. Deep-Sea Res I. 48, 529-553.

Sayles, F.L., Martin, W.R., Deuser, D., 1994. Response of benthic oxygen demand to particulate organic carbon supply in the deep-sea near Bermuda. Nature 371, 686-689.

Sundby, B., Anderson, L.G., Hall, P.O.J., Iverfeldt, ̊̊., Rutgers Van Der Loeff, M.M., Westerlund, S.F.G., 1986. The effect of oxygen on release uptake of cobalt, manganese, iron and phosphate at the sediment-water interface. Geochim. Cosmochim. Acta 50, 1281-1288.

Sweerts, J.P.R.A., Cappenberg, T.E., 1988. Use of microelectrodes for measuring oxygen profiles in lake sediments. Arch. Hydrobiol. Beih. Ergben. Limnol. 31, 365-371.

Thamdrup, B., Fossing, H., Jørgensen, B.B., 1994. Manganese, iron, and sulphur cycling in a coastal marine sediment, Aarhus Bay, Denmark. Geochim. Cosmochim. Acta 58, 5115-5129.

Thomas, R.C., 1978. Construction and testing of recessed-tip pH-sensitive micro-electrode, proceedings. J. Physiol 277, 14-15.

Ullman, W.J., Aller, R.C., 1982. Diffusion coefficients in near shore marine sediments. Limnol. Oceanogr 27, 552-556.

Van Ryssen, R., Alam, M., Goeyens, L., Baeyens, W., 1998. The use of flux-corer experiments in the determination of heavy metal re-distribution in and of potential leaching from the sediments. Water Sci. Technol 37, 283-290.

Westerlund, S.F.G., Anderson, L.G., Hall, P.O.J., Iverfeldt, ̊̊., Rutgers Van Der Loeff, M.M., Sundby, B., 1986. Benthic fluxes of cadmium, copper, nickel, zinc, and lead in the coastal environment. Geochim. Cosmochim. Acta 50, 1289-1296.

Zimmerman, A.R., Canuel, E.A., 2000. A geochemical record of eutrophication and anoxia in Chesapeake Baysediments: anthropogenic influence on organic matter composition. Mar. Chem 69, 117-137.

Zoumis, T., Schmidt, A., Grigorova, L., Calmano, W., 2001. Contaminants in sediments: remobilisation and demobilisation. Sci. Total Environ 266, 195-202. 